\title{
Neonatal outcome and diabetes course in children with GCK-MODY born from women with GCK-MODY
}

\author{
Wyniki neonatologiczne i przebieg cukrzycy u dzieci z GCK-MODY urodzonych przez kobiety \\ z rozpoznaną cukrzycą GCK-MODY
}

\author{
${ }^{1 *}$ Katarzyna Kopacz-Petranyuk, ${ }^{2 *}$ Agnieszka Brandt-Varma, ${ }^{3}$ Marta Buraczewska, \\ ${ }^{2}$ Anna Wołoszyn-Durkiewicz, ${ }^{4}$ Jagoda Peczyńska, ${ }^{2}$ Krzysztof Preis, ${ }^{5}$ Przemysława Jarosz-Chobot, \\ ${ }^{6}$ Agnieszka Szadkowska, ${ }^{6}$ Wojciech Młynarski, ${ }^{1}$ Małgorzata Myśliwiec \\ *These authors contributed equally to this study.
}

\author{
${ }^{1}$ Department of Obstetrics, Medical University of Gdansk, Poland \\ ${ }^{2}$ Clinic of Pediatrics, Diabetology and Endocrinology, Medical University of Gdansk, Poland \\ ${ }^{3}$ Department of Neonatology, Specialized Hospital in Wejherowo, Poland \\ ${ }^{4}$ Specialistic Center for Internistic Diabetology in Bialystok, Poland \\ ${ }^{5}$ Department of Children's Diabetology, Medical University of Silesia, Katowice, Poland \\ ${ }^{6}$ Department of Paediatrics, Oncology, Hematology and Diabetology, Medical University of Lodz, Poland
}

\begin{abstract}
Introduction: Gestational diabetes is one of the most common medical disorders and may cause numerous of maternal and foetal complications, such as: preterm births, congenital defects, hypertrophic cardiomyopathy, metabolic changes, and macrosomia in neonates. One of the types of diabetes that may clinically manifest in pregnancy is GCK-MODY, caused by mutations in the glucokinase (GCK) gene. Aim of the study: The aim of the study was to assess the impact of diabetes during pregnancy in women with GCK-MODY on their children's health outcome and to determine the clinical and biochemical characteristics of children delivered by patients with GCK-MODY. Material and methods: Study was multicentre, involving 50 children from paediatric diabetology departments in Gdansk, Katowice, Bialystok, and Lodz. The risk of GCK-MODY was evaluated on the basis of the medical history of the patient, the clinical course of the disease, and laboratory tests performed during diagnostic procedures. Data concerning family history, mothers' health status, course of pregnancy, and perinatal period was collected.

Results: The study showed that among children with glucokinase mutation, born by mothers affected with GCK-MODY, 62\% received 10 points in Apgar score in the first minute of life, whereas 92\% $(n=46)$ obtained 10 points in Apgar score in the fifth minute of life. The average age of diagnosis of GCK-MODY in children was $8.25 \pm 4.76$ years, and the average $\mathrm{HbA}_{1 \mathrm{c}}$ during diagnosis was $6.43 \pm 0.71 \%$. Statistically significant difference between the absence of macrosomia (birth weight $>91^{\text {st }}$ percentile) in children with GCK-MODY diabetes in comparison to the general paediatric population $(p=0.0229)$ was observed.

Conclusion: According to the presented study, possible consequences of GCK-MODY during pregnancy on foetal development are generally less severe and may differ from those characteristic for other types of diabetes. Children born by mothers with diabetes should be followed up regarding glucose disorders. Further investigation of particular phenotypes of GCK-MODY, depending on the type of inherited mutation in mothers and their children, is required.
\end{abstract}

Key words:

gestational diabetes, GCK-MODY, newborn.

\section{Streszczenie}

Wprowadzenie: Cukrzyca ciążowa stanowi jeden z najczęstszych problemów zdrowotnych w trakcie ciąży i może prowadzić do wielu powikłań, takich jak: poród przedwczesny, wady wrodzone, kardiomiopatia przerostowa, zmiany metaboliczne i makrosomia u noworodka. Jednym z rodzajów cukrzycy, który może objawiać się klinicznie w ciąży, jest GCK-MODY, wywołana mutacjami w genie glukokinazą (GCK). 
Cel pracy: Ocena wpływu cukrzycy w czasie ciąży u kobiet dotkniętych GCK-MODY na wyniki zdrowotne ich dzieci oraz ustalenie klinicznych i biochemicznych cech dzieci urodzonych przez pacjentki z GCK-MODY.

Materiał i metody: Badanie było wieloośrodkowe, do badania włączono 50 dzieci z oddziałów diabetologii dziecięcej w Gdańsku, Katowicach, Białymstoku i Łodzi. Ryzyko wystąpienia GCK-MODY oceniano na podstawie wywiadu medycznego pacjenta, przebiegu klinicznego choroby oraz badań laboratoryjnych. Zebrano dane dotyczące wywiadu rodzinnego, stanu zdrowia matek, przebiegu ciąży i okresu okołoporodowego.

Wyniki: Badanie wykazało, że wśród dzieci z mutacją glukokinazy, urodzonych przez matki dotknięte GCK-MODY, 62\% otrzymało 10 punktów w skali Apgar w pierwszej minucie życia, natomiast 92\% ( $n=46)$ uzyskało 10 punktów w skali Apgar w piątej minucie życia. Średni wiek rozpoznania GCK-MODY u dzieci wynosił 8,25 $\pm 4,76$ roku, a średni poziom hemoglobiny glikowanej (HbA $\left.{ }_{1 c}\right)$ podczas diagnozy $6,43 \pm 0,71 \%$. Zaobserwowano statystycznie istotną różnicę między brakiem makrosomii (masa urodzeniowa $>$ 91. percentyla) u dzieci z cukrzycą GCK-MODY w porównaniu z ogólną populacją pediatryczną $(p=0,0229)$.

Wnioski: Według przedstawionych badań, możliwe konsekwencje GCK-MODY podczas ciąży na rozwój płodu są mniej poważne i mogą różnić się od charakterystycznych dla innych typów cukrzycy. Dzieci urodzone przez matki chore na cukrzycę powinny być monitorowane w odniesieniu do zaburzeń glukozy. Konieczne są dalsze badania poszczególnych fenotypów GCK-MODY, w zależności od rodzaju odziedziczonej mutacji u matek i ich dzieci.

Słowa kluczowe:

cukrzyca ciążowa, GCK-MODY, noworodek.

\section{Introduction}

Gestational diabetes is one of the most common medical disorders and may cause numerous maternal and foetal complications [1]. It constitutes one of the most frequent pregnancy health problems next to hypertension, anaemia, proteinuria, and urinary tract infections. Therefore, early gestational diabetes detection and implementation of guideline-based screening tests prepared by experts are crucial. Risk factors for gestational diabetes include: maternal age over 35 years, polycystic ovary syndrome, history of macrosomia or congenital malformations in newborns in a previous pregnancy, hypertension, overweight, previous pregnancy loss, family history of diabetes mellitus type 2, gestational diabetes in previous pregnancies, and pluriparity. Current epidemiological data concerning the prevalence of gestational diabetes in study populations is ambiguous. The incidence rate of gestational diabetes is estimated at about 3-20\% of pregnancies [1, 2].

The first described form of maturity-onset diabetes of the young (MODY) was MODY-2. The disorder is caused by mutations in the glucokinase (GCK) gene on chromosome 7. As a result, it leads to pancreatic beta cells dysfunction. The first mutation of GCK gene was detected in 1992 [3]. The clinical presentation of diabetes caused by glucokinase mutations, is mild and fasting glucose levels are slightly elevated. The disorder is most commonly diagnosed before the age of 35 years. GCK gene mutations are inherited in an autosomal dominant way $[4,5]$.

Fasting hyperglycaemia along with much lower two-hour post-load glucose concentration in oral glucose tolerance test than would be expected from the impaired fasting glycaemia, is characteristic for GCK-MODY. Glycated haemoglobin level is mildly elevated and ketoacidosis is rarely observed in this type of diabetes [6].

Usually, genetic testing in patients with gestational diabetes is not performed, thus this form of diabetes is frequently underestimated. In most cases after labour, diabetes care is no longer provided to the patient and her newly born child.
Due to a complicated and expensive diagnostic procedure, there is a lack of objective population studies, thus the incidence rate of all of the types of monogenic diabetes is difficult to assess. However, probably $1 \%$ of patients under 25 years of age are affected with MODY. The prevalence of GCK-MODY in the general population is difficult to estimate as well, owing to the absence of significant symptoms and mild hyperglycaemia [2]. According to various publications, GCK-MODY is present in $20-50 \%$ of patients with genetically determined diabetes [7, 8]. In Great Britain the prevalence of MODY-2 is assessed at 20\% [9].

Glucose is the main energy source for the foetus. Foetal glucose consumption is around $6 \mathrm{mg} / \mathrm{min}$ and is two times higher than in adults. Glucose crosses the placental barrier by diffusion, and its concentration in foetal blood is about $10-20 \mathrm{mg} / \mathrm{dl}$ lower than in pregnant women's blood. Developmental defects are detected in 6-9\% of gestational diabetes pregnancies and in $1-2 \%$ of pregnancies in the general population. It refers almost exclusively to pregestational diabetes. The increasing incidence rate of congenital defects due to gestational diabetes should be primarily linked with diabetes that existed prior to conception but was detected during pregnancy. Sacral agenesis is more frequently observed in infants of diabetic mothers than in the general population (the incidence rate is 200-600 times higher). The risk of cardiovascular defects is five times higher, and the risk of central nervous system malformations is 10 times higher. The incidence rate of congenital defects was decreased to $0.8 \%$ in patients with normoglycaemia during organogenesis, in comparison to $7.5 \%$ of women, whose diabetes was not managed properly during this crucial period of pregnancy $[10,11]$.

Metabolic changes in gestational diabetes can lead to retardation of foetal development. Between the seventh and fourteenth week of pregnancy foetuses of diabetic mothers are retarded in development by five days in comparison to foetuses of nondiabetic mothers. Therefore, it may be a cause of low birth weight in infants of diabetic mothers. In the group of patients with gestational diabetes, $10-30 \%$ are expected to give 
birth preterm. Preterm labours occur more frequently than in nondiabetic mothers. It should be noted that preterm births are associated with many neonatal complications, such as hypoxia, periventricular and intraventricular haemorrhage, respiratory distress syndrome, or infections.

The incidence rate of macrosomia in neonates of diabetic mothers $(25-40 \%)$ is much higher than in the general population (8-14\%). Macrosomia is usually observed in infants of mothers who have a short history of diabetes and were significantly overweight or those who already gave birth to an infant with birth weight over $4000 \mathrm{~g}$. Hyperglycaemia during pregnancy is reported to be the major cause of macrosomia. Maternal hyperglycaemia causes foetal hyperglycaemia and hyperinsulinaemia, which in turn stimulates lipogenesis and leads to adipose tissue development [12]. Macrosomic infants are born with birth weight between 4000 and $4500 \mathrm{~g}$ and are predisposed to birth injuries, especially those with undiagnosed macrosomia. A much less common complication of gestational diabetes is hypotrophy. Hypotrophy is defined as birth weight below the sex-specific 10th percentile for gestational age.

Intrauterine hypotrophy is observed among infants whose mothers have a long history of diabetes and suffer from vascular complications. Hypotrophic neonates have a higher incidence rate of perinatal shock, acute hypoxia, hypoglycaemia, hypocalcaemia, and polycythaemia [12].

Moreover, in the first hours of life, newborns of diabetic mothers are at risk of metabolic complications such as hypoglycaemia (25-50\%), hypocalcaemia (10-50\%), and hypomagnesaemia (30-75\%). Aforementioned metabolic disorders may be manifested by symptoms of central nervous and cardiovascular systems, including drowsiness, apathy, anxiety, limb tremors, seizures, cyanosis, and apnoea, finally leading to circulatory failure and cardiac arrest [13].

Prolonged hypoglycaemia is a particularly important consideration because it may cause intracranial haemorrhage and cerebral cortex damage in a child $[11,12]$.

In addition, newborns of diabetic mothers, in comparison to newborns of healthy women, are at higher risk of hyperbilirubinaemia. Another major complication, frequently encountered in neonates of diabetic patients (10-50\%), is hypertrophic cardiomyopathy. The disorder may be asymptomatic or can be manifested by cardiac failure. Echocardiography reveals thickened septum and ventricular walls as well as left ventricular outflow tract obstruction. Usually, the condition is transient and echocardiographic dimensions normalise within the first year of life [12].

\section{Aim of the study}

The aim of the study was to assess the impact of diabetes during pregnancy in women affected with GCK-MODY on neonatal health outcome, and a trial to determine the clinical and biochemical characteristics of children delivered by women with GCK-MODY.

\section{Material and methods}

The study population included children who were under care in the Department of Paediatrics, Diabetology, and Endocrinology in Gdansk, the Department of Endocrinology and Diabetology of the Medical University of Silesia, the Department of Paediatrics, Endocrinology, and Diabetology with the Cardiology Unit of the Medical University in Bialystok, and the Department of Paediatrics, Oncology, Haematology, and Diabetology of the Medical University in Lodz.

Patients diagnosed with GCK-MODY and subjects with a suspicion of genetically determined diabetes were enrolled in the study retrospectively and prospectively.

The risk of GCK-MODY was evaluated on the basis of the medical history of the patient, clinical course of the disease, and laboratory tests performed during diagnostic procedures.

Diabetes was diagnosed according to Polish Diabetes Association criteria (PTD).

The study population included 50 children. Data concerning the course of pregnancy and mothers' health status was collected.

Researchers gathered general information about patients sex, date of birth, age, and presented symptoms at time of diagnosis of diabetes. Data from family history included presence of type 1 and type 2 diabetes, gestational diabetes, monogenic diabetes, carbohydrate and lipid disorders, as well as reported vascular complications such as myocardial infarction or stroke. Perinatal data comprised method of delivery, birth weight and length, gestational week in which a child was born, Apgar in first and fifth minute of life, and occurrence of hyperglycaemia or hypoglycaemia after birth.

\section{Results}

Mean age of the patients enrolled to the study was 11.17 \pm 4.92 years, and the mean age at the time of diagnosis of GCK-MODY was $8.25 \pm 4.76$ years (Table I).

The study revealed that the majority of children of mothers affected with GCK-MODY were born in term, i.e. after the $38^{\text {th }}$

Table I. Age of the patients with GCK-MODY at the diagnosis and during study

\begin{tabular}{lll}
\hline Parameter & $\begin{array}{l}\text { Actual age } \\
\text { (years) }\end{array}$ & $\begin{array}{l}\text { Age of diagnosis } \\
\text { (years) }\end{array}$ \\
\hline Avarage & 11.17 & 8.25 \\
\hline Standard deviation & 4.92 & 4.76 \\
\hline Median & 12.25 & 9.50 \\
\hline Minimum value & 0.50 & 0.50 \\
\hline Maximum value & 20.00 & 18.00 \\
\hline
\end{tabular}


Kopacz-Petranyuk K., Brandt-Varma A., Buraczewska M., Wołoszyn-Durkiewicz A., Peczyńska J., Preis K., Jarosz-Chobot P., Szadkowska A., Młynarski W., Myśliwiec M.

Table II. Birth weight and length of children with GCK-MODY

\begin{tabular}{lll}
\hline Parameter & $\begin{array}{l}\text { Birth weight } \\
\text { masa }(\mathrm{g})\end{array}$ & Birth lenght $(\mathrm{cm})$ \\
\hline Avarage & 3356.80 & 53.30 \\
\hline Standard deviation & 557.53 & 4.41 \\
\hline Median & 3480.00 & 54.00 \\
\hline Minimum value & 1760.00 & 31.00 \\
\hline Maximum value & 4160.00 & 59.00 \\
\hline
\end{tabular}

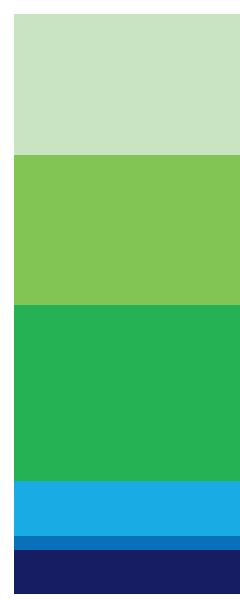

General population

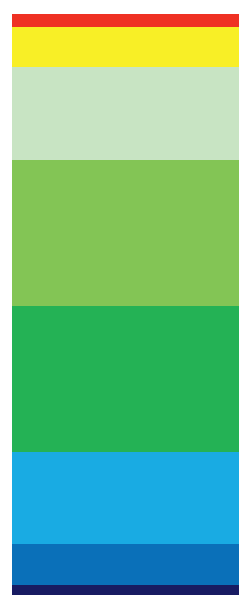

GCK-MODY
Figure 1. Distribution of birth weight in patients with GCK-MODY in comparison to general population completed week of pregnancy, whereas $6 \%$ of children were born premature, before completing the $38^{\text {th }}$ week.

In the study population, mean birth weight was 3356.80 $\pm 557.53 \mathrm{~g}$, and the lowest birth body weight of an infant diagnosed with GCK-MODY was $1760 \mathrm{~g}$. Mean birth length was $53.3 \pm 4.41 \mathrm{~cm}$ (Table II).

Left Fisher test demonstrated a statistically significant difference between the absence of macrosomia (birth weight $>91^{\text {st }}$ percentile) in children with GCK-MODY diabetes in comparison to the general paediatric population ( $p=0.0229$; Fig. 1 ).

Among children with glucokinase mutation, born by mothers affected with GCK-MODY, 62\% $(n=32)$ received 10 points in Apgar score in the first minute of life, whereas $92 \%(n=46)$ obtained 10 points in Apgar score in the fifth minute of life. Two patients received less than 7 points in Apgar score in the first minute of life.

In the study group the mean fasting glucose concentration was $120 \pm 20 \mathrm{mg} / \mathrm{dl}$, whereas the mean glucose levels 60 and 120 minutes after oral glucose load were, respectively, $208 \pm 35 \mathrm{mg} / \mathrm{dl}$ and $175 \pm 38 \mathrm{mg} / \mathrm{dl}$. Median values of fasting insulinaemia 60 and 120 minutes after oral glucose load were, respectively, $34 \mathrm{IU} / \mathrm{ml}$ and $29 \mathrm{IU} / \mathrm{ml}$. Mean glycated haemoglobin level at the time of the diagnosis was $6.43 \pm 0.71 \%$ and mean fasting C-peptide value was $1.26 \pm 0.62 \mathrm{ng} / \mathrm{ml}$ (Table III).

In the studied group of children, the median level of antiglutamic acid antibodies was $0.74(n<5)$, islet antibodies was $10(n<20)$, and anti-insulin antibodies was $3.6(n<5)$. In four children with GCK-MODY antibodies were positive, i.e. in $8 \%$ of patients.

In patients who were treated with insulin the daily dose was between 0.14 do 0.7 unit $/ \mathrm{kg} /$ day (median $0.26 \mathrm{u} / \mathrm{kg} /$ day) (Table III).

In the studied group of patients, a positive significant correlation between fasting glucose levels in mothers and birth weight in babies was seen $(R=0.64 ; p<0.05$; Fig. 2$)$. Also, positive correlation between mothers' and children's $\mathrm{HbA}_{1 \mathrm{c}}$ was seen.

Table III. Biochemical parametres in study population of children with GCK-MODY at the time of diagnosis

\begin{tabular}{|c|c|c|c|c|c|c|c|c|c|}
\hline Parameter & $\begin{array}{l}\text { Fasting } \\
\text { glucose } \\
\text { (mg/dl) }\end{array}$ & $\begin{array}{l}\text { Fasting } \\
\text { insulin } \\
(\mathrm{IU} / \mathrm{ml})\end{array}$ & $\begin{array}{l}\text { Glucose } \\
1 \mathrm{~h} \text { OGTT } \\
(\mathrm{mg} / \mathrm{dl})\end{array}$ & $\begin{array}{l}\text { Insulin } \\
1 \mathrm{~h} \text { OGTT } \\
(\mathrm{IU} / \mathrm{ml})\end{array}$ & $\begin{array}{l}\text { Glucose } \\
2 \text { h OGGT } \\
(\mathrm{mg} / \mathrm{dl})\end{array}$ & $\begin{array}{l}\text { Insulin } \\
2 \mathrm{~h} \text { OGTT } \\
(\mathrm{IU} / \mathrm{ml})\end{array}$ & $\mathrm{HbA}_{1 \mathrm{c}}(\%)$ & $\begin{array}{l}\text { Fasting } \\
\text { C-peptide } \\
\text { (ng/ml) }\end{array}$ & $\begin{array}{l}\text { Daily } \\
\text { dose } \\
\text { of insulin } \\
(\cup / k g)\end{array}$ \\
\hline Avarage & 120 & 5.90 & 208 & 41.9 & 176 & 36 & 6.43 & 1.26 & 0.34 \\
\hline $\begin{array}{l}\text { Standard } \\
\text { deviation }\end{array}$ & 20 & 5.62 & 35 & 29.6 & 39 & 27.6 & 0.71 & 0.62 & 0.21 \\
\hline Median & 119 & 3.4 & 204 & 34.23 & 168 & 29.7 & 6.36 & 1.30 & 0.26 \\
\hline $\begin{array}{l}\text { Minimum } \\
\text { value }\end{array}$ & 57 & 0.20 & 145 & 5.7 & 99 & 9.6 & 5.00 & 0.42 & 0.14 \\
\hline $\begin{array}{l}\text { Maximum } \\
\text { value }\end{array}$ & 200 & 17.1 & 295 & 87.2 & 297 & 114.0 & 9.81 & 2.72 & 0.70 \\
\hline
\end{tabular}


In the presented study, no perinatal deaths, congenital malformations, or episodes of hypoglycaemia, were reported in infants of GCK-MODY mothers.

In the conducted analysis correlation between $\mathrm{HbA}_{1 \mathrm{c}}$ in mothers and birth weight in children, and between glucose levels in children and the age of diagnosis, were not detected. We did not find any relation between weight gain in pregnancy by mothers, their $\mathrm{HbA}_{1 \mathrm{c}}$, fasting glucose levels in mothers, and APGAR score in children.

\section{Discussion}

Diabetes during pregnancy is a heterogenous disorder. GCK-MODY, caused by glucokinase defect, along with type 1 and type 2 diabetes, is considered as one of the most frequent types of diabetes in pregnancy $[13,14]$.

GCK-MODY is underdiagnosed on account of the mild clinical course of this disease. In addition, in a substantial percentage of women, period of pregnancy is the only time when screening and diagnosis of carbohydrate metabolism disorders are carried out.

Early diagnosis of GCK-MODY enables us to optimise diabetes care of both pregnant women and foetuses. Moreover, it allows us to implement preventive procedures against diabetes development after delivery $[13,15,16]$. It should be noted that due to the dominant pattern of inheritance of GCK-MODY, there is a high risk of transmission of mutated gene to the offspring, which can lead to diabetes presentation even in the first months of life $[15,17,18]$.

Several parameters, which may be influenced by diabetes, were assessed in neonates of GCK- MODY mothers. Researchers investigated birth weight, perinatal condition, and the presence of congenital malformations in patients.

The incidence rate of foetal macrosomia in the general population is $8-14 \%$, whereas in diabetic mothers it varies between 25 and $42 \%$. Macrosomia is mainly caused by hyperglycaemia in pregnant women. Intrauterine hypotrophy, a contrasting disorder, occurs in patients with a long history of diabetes, who present vascular complications such as nephropathy and retinopathy [19]. The presence of inactivating GCK mutation in pregnant women may lead to increased birth body weight in newborns. On the other hand, if the foetus carries the mutation, its birth weight is decreased due to reduction of insulin secretion [20].

In the presented study, glucokinase gene mutation was detected in all of the infants of GCK-MODY mothers. The birth weight in the study group was similar to the mean birth weight in the general population. There were no macrosomic neonates of patients with GCK-MODY. Moreover, a statistically significant difference in the absence of macrosomia was revealed between the study group and the general paediatric population. In observed patients, levels of glycaemia, insulinaemia, and, indirectly, birth weight were influenced by the presence of GCK-MODY in mothers and inheritance of GCK mutation by foetuses. It is presumed that opposite action of maternal hyperglycaemia, which stimulates insulin secretion,

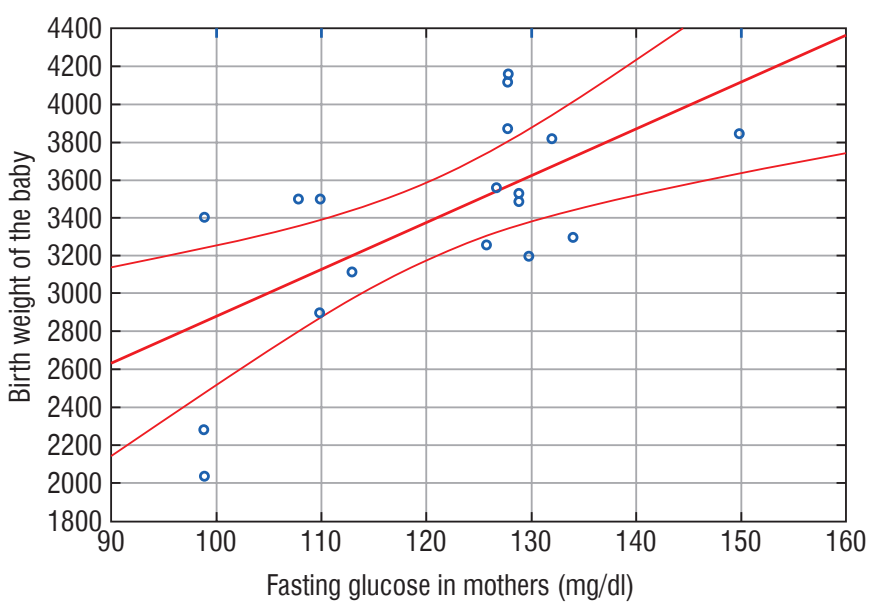

Figure 2. Relation between fasting glucose level in mother $(\mathrm{mg} / \mathrm{dl})$ and birth weight of the babys $(\mathrm{g})$

and hyposecretion of insulin in foetuses, conclusively leads to normal birth weight. Furthermore, researchers stated a statistically significant positive correlation between fasting glycaemia in mothers and birth weight in newborns. This phenomenon may be explained by the anabolic action of insulin in foetuses in response to hyperglycaemia in mothers.

The majority of examined neonates with glucokinase gene mutation, who were delivered by patients affected with GCKMODY, received 10 points in the Apgar scale (62\% in the first minute of life, $92 \%$ in the fifth minute of life). According to literature data, the achieved result is much more satisfying than the score obtained by newborns of mothers with gestational diabetes.

In Kock et al.'s study concerning infants of patients with gestational diabetes, the mean Apgar score was 8.4 points in the first minute [21]. In Wender-Ożegowska et al.'s research the achieved result was similar at 8 points [22]. The better clinical state of newborns delivered by patients with GCK-MODY in comparison with subjects affected with other types of diabetes probably results from the milder clinical course of this disorder.

Another parameter investigated in the presented study was the incidence rate of perinatal deaths and congenital defects in newborns of GCK-MODY mothers. According to the literature data, it can be concluded that diabetes during pregnancy predisposes to perinatal deaths. In Czajkowski et al.'s work [23] the incidence rate was $6.6 \%$. A similar result was obtained in Cypryk et al.'s study. Researchers reported perinatal deaths in $6.4 \%$ of neonates of diabetic patients $[23,24]$ in comparison with $1.4 \%$ of newborns of healthy mothers [25].

In the presented study, perinatal deaths, congenital malformations, and episodes of hypoglycaemia were not reported in infants of GCK-MODY mothers. This can be explained by the mild clinical course of monogenic diabetes. An additional factor, which might have influenced the absence of hypoglycaemia after birth, was the genetic defect of glucokinase detected in the whole group of examined children. 
Kopacz-Petranyuk K., Brandt-Varma A., Buraczewska M., Wołoszyn-Durkiewicz A., Peczyńska J., Preis K., Jarosz-Chobot P., Szadkowska A., Młynarski W., Myśliwiec M.

Mean fasting glucose concentration in the examined children was $120 \mathrm{mg} / \mathrm{dl}$, whereas 120 minutes after glucose load the mean glucose concentration was $175 \mathrm{mg} / \mathrm{dl}$. The achieved results were consistent with typical clinical features of GCKMODY [4]. At the moment of diagnosis of the disease, the glycated haemoglobin level presented by children was $6.43 \%$ and was higher than in their mothers at the moment of diagnosis. In the group of patients treated with insulin, the total daily dose of insulin was usually around $0.26 \mathrm{U} / \mathrm{kg} / 24$ hours; a much lower dose than in patients affected with type 1 diabetes. Such low insulin requirements, comparable to those required by type 1 diabetic patients during remission period, raise doubts about the need for insulin therapy in the examined patients. However, it should be noted that in certain patients insulin therapy was implemented due to a suspicion of type 1 diabetes, before making a diagnosis of GCK-MODY, and that $8 \%$ of studied patients had positive antibodies.

Furthermore, a positive correlation between $\mathrm{HbA}_{1 \mathrm{c}}$ levels in patients with glucokinase mutation and $\mathrm{HbA}_{1 \mathrm{c}}$ levels in their mothers was reported, which indicates the presence of the

\section{References}

1. Imam K. Gestational diabetes mellitus. Adv Exp Med Biol 2012; 771 : 24-34.

2. Tieu J, McPhee AJ, Crowther CA, et al. Screening for gestational diabetes mellitus based on different risk profiles and settings for improving maternal and infant health. Cochrane Database Syst Rev 2017; 8: CD007222. doi: 10.1002/14651858.CD007222.pub4.

3. Osbak KK, Colclough K, Sanit-Martin C, et al. Update on Mutations in Glucokinase (GCK), Which Cause Maturity-Onset Diabetes of the Young, Permanent Neonatal Diabetes, and Hyperinsulinemic Hypoglycemia. Hum Mutat 2009; 11: 1512-1526. doi: 10.1002/humu.21110.

4. Fajans SS, Bell GI, Polonsky KS. Molecular mechanisms and clinical pathophysiology of maturity-onset diabetes of the young. $\mathrm{N}$ Engl J Med 2001; 345: 971-980. doi: 10.1056/NEJMra002168

5. Hattersley AT. Maturity-onset diabetes of the young: clinical heterogeneity explained by genetic heterogeneity. Diabet Med 1998; 15: 15-24. doi: 10.1002/(SICl)1096-9136(199801)15:1<15::AIDDIA562>3.0.CO;2-M

6. Hussain K. Mutations in pancreatic $\beta$-cell Glucokinase as a cause of hyperinsulinaemic hypoglycaemia and neonatal diabetes mellitus. Rev Endocr Metab Disord 2010; 11: 179-218. doi: 10.1007/s11154010-9147-z

7. Massa O, Meschi F, Cuesta-Munoz A, et al. Italian Society of Paediatic Endocrinology and Diabetes (SIEDP): High prevalence of glucokinase mutations in Italian children with MODY. Influence on glucose tolerance, first-phase insulin response, insulin sensitivity and BMI. Diabetes Study Group of the Italian Society of Paediatric Endocrinology and Diabetes (SIEDP). Diabetologia 2001; 44: 898-905.

8. Yorifuji T, Fujimaru R, Hosokawa Y, et al. Comprehensive molecular analysis of Japanese patients with pediatric-onset MODY-type diabetes mellitus. Pediatr Diabetes 2011; 8. doi: 10.1111/j.13995448.2011.00827.x same type of mutation as well as the phenotype and severity of clinical symptoms related to it.

\section{Conclusions}

Gestational diabetes is one of the most common medical disorders and may cause numerous maternal and foetal complications. Carbohydrate metabolism disorders are frequently detected during pregnancy. One of the types of diabetes that may clinically manifest in pregnancy is GCK-MODY. The clinical course of the disease is mild. Patients usually present slightly elevated fasting glucose concentration. According to the presented study, possible consequences of GCK-MODY during pregnancy on foetal development are generally less severe and may differ from those characteristic for other types of diabetes. Further investigation of particular phenotypes of GCK-MODY, depending on the type of inherited mutation, in mothers and their children is required.

9. Frayling TM, Evan JC, Bulman MP, et al. B-cell genes and diabetes: molecular and clinical characterisation of mutations in transcription factors. Diabetes 2001; 50: 94-100.

10. Cypryk K, Jędrzejewska E, Sobczak M, et al. Ciąża powikłana cukrzycą. Wyzwanie XXI wieku. Służba Zdrowia 2001; 3033-3036: 39-41.

11. Noczyńska A. Ocena wpływu cukrzycy ciężarnych na stan urodzeniowy dzieci. Diabetologia Polska 2001; 8: 257-263.

12. Kinalski M, Śledziewski A, Kuźmicki M. Wskaźniki ryzyka ujawnienia się cukrzycy ciężarnych. Diabetol Prakt 2003; 4: 257-265.

13. Lambrinoudaki I, Vlachou SA, Creatsas G. Genetics in gestational diabetes mellitus: association with incidence, severity, pregnancy outcome and response to treatment. 2010; 6: 393.

14. Shaat N, Groop L. Genetics of gestational diabetes mellitus. Curr Med Chem 2007; 14: 569-583.

15. Ellard S, Beards F, Allen L, et al. A high prevalence of glucokinase mutations in gestational diabetic subjects selected by clinical criteria. Diabetologia 2000; 43: 250-253. doi: 10.1007/s001250050038

16. Weng J, Ekelund M, Lehto M, et al. Screening for MODY mutations, GAD antibodies, and type 1 diabetes-associated HLA genotypes in women with gestational diabetes mellitus. Diabetes Care 2002; 25: 68.

17. Page R, Hattersley A, Levy J, et al. Clinical characteristics of subjects with missense mutation in glucokinase. Diabet Med 1995; 12: 209-212.

18. Ryan EA. Pregnancy in diabetes. Med Clin North Am 1998; 82: 823.

19. Łagoda K, Kobus G, Bachorzewska-Gajewska H. Influence of getational diabetes on fetal and neonatal growth. Endokrynol Otyl Zab Przem Mat 2008; 4: 168-173.

20. Doria A, Yang Y, Malecki M, et al. Phenotypic characteristics of early-onset autosomal-dominant type 2 diabetes unlinked to known maturity-onset diabetes of the young (MODY) genes. Diabetes Care 1999; 22: 253-261.

21. KöckK, KöckF, Klein K, etal. Diabetes mellitus and risk of preterm birth with regard to risk of spontaneous preterm birth. J Matern Fetal Neonatal Med 2010; 23: 1004-1008. doi: 10.3109/14767050903551392. 
22. Wender-Ożegowska E, Gutaj P, Szczepanek U, et al. Planowanie ciąży a wyniki położnicze u kobiet z cukrzycą przedciążową. Ginekol Pol 2010; 81: 762-767.

23. Czajkowski K, Malinowska-Polubiec A, Sotowska A, et al. Niepowodzenia położnicze w cukrzycy przedciążowej. Klin Perinatol Ginekol 2007; 43: 32-35.

24. Cypryk K, Wender-Ożegowska E. Problemy ginekologiczno-położnicze. Otto-Buczkowska E. Cukrzyca typu 1. Cornetis, Wrocław 2006; 403-422.
25. Cypryk K, Wilczyński J, Loba J, et al. Niepowodzenia położnicze w ciąży powikłanej cukrzycą - badania własne. Diabetol Pol 1995; 2: $12-17$

26. Fuhrmann K, Reiher H, Semmler K, et al. Prevention of congenital malformations in infants of insulin-dependent diabetic mothers. Diabetes Care 1983; 6: 219-223. 